\title{
Building a nation: The Jeroboams and the creation of two Israels
}

\begin{tabular}{|c|c|}
\hline \multicolumn{2}{|c|}{$\begin{array}{l}\text { Author: } \\
\text { Philip Davies }{ }^{1,2} \uparrow\end{array}$} \\
\hline \multicolumn{2}{|c|}{$\begin{array}{l}\text { Affiliations: } \\
\text { 'Department of Biblical } \\
\text { Studies, University of } \\
\text { Sheffield, England, } \\
\text { United Kingdom }\end{array}$} \\
\hline $\begin{array}{l}{ }^{2} \text { Department } 0 \\
\text { Testament Stu } \\
\text { of Theology an } \\
\text { University of P } \\
\text { Pretoria, Soutt }\end{array}$ & $\begin{array}{l}\text { f Old } \\
\text { dies, Faculty } \\
\text { d Religion, } \\
\text { retoria, } \\
\text { h Africa }\end{array}$ \\
\hline \multicolumn{2}{|c|}{$\begin{array}{l}\text { Research Project Registration: } \\
\text { Project Leader: J.H. le Roux }\end{array}$} \\
\hline \multicolumn{2}{|c|}{$\begin{array}{l}\text { Description: } \\
\text { This research is part of the } \\
\text { project of Prof Jurie le Roux, } \\
\text { Emeritus Professor in the } \\
\text { Department of Old Testament } \\
\text { Studies, Faculty of Theology } \\
\text { and Religion, University of } \\
\text { Pretoria. }\end{array}$} \\
\hline \multicolumn{2}{|c|}{$\begin{array}{l}\text { Corresponding author: } \\
\text { Philip Davies, } \\
\text { p.davies@sheffield.ac.uk }\end{array}$} \\
\hline \multicolumn{2}{|c|}{$\begin{array}{l}\text { Dates: } \\
\text { Received: } 08 \text { Apr. } 2018 \\
\text { Accepted: } 14 \text { May } 2019 \\
\text { Published: } 29 \text { July } 2019\end{array}$} \\
\hline \multicolumn{2}{|c|}{$\begin{array}{l}\text { How to cite this article: } \\
\text { Davies, P., 2019, 'Building a } \\
\text { nation: The Jeroboams and } \\
\text { the creation of two Israels', } \\
\text { HTS Teologiese Studies/ } \\
\text { Theological Studies } 75(3) \text {, } \\
\text { a5018. https://doi.org/ } \\
\text { 10.4102/hts.v75i3.5018 }\end{array}$} \\
\hline \multicolumn{2}{|c|}{$\begin{array}{l}\text { Copyright: } \\
\text { C 2019. The Authors. } \\
\text { Licensee: AOSIS. This work } \\
\text { is licensed under the } \\
\text { Creative Commons } \\
\text { Attribution License. }\end{array}$} \\
\hline \multicolumn{2}{|l|}{ Read online: } \\
\hline 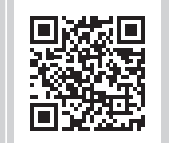 & $\begin{array}{l}\text { Scan this QR } \\
\text { code with your } \\
\text { smart phone or } \\
\text { mobile device } \\
\text { to read online. }\end{array}$ \\
\hline
\end{tabular}

This article represents a short reflective essay in honour of the Old Testament scholar Eben Scheffler. It focuses on the writing of the history of ancient Israel texts; examines different approaches to address the history of texts: minimalist and maximalist; and illustrates a minimalist approach in reference to the figure of the Israelite king Jeroboam II.

Keywords: Jeroboam and Jeroboam; Israel; Nationhood; Old Testament scholarship; Northern Kingdom.

It is a great pleasure for me to offer this short essay to my friend and colleague Eben Scheffler, of whom I have very fond memories both in South Africa and in various conference venues around the world. He is not only a valued friend but also a scholar whose range of interests invites scholarly conversation on almost any topic - and a true biblical scholar, in the sense that he has engaged with both Testaments and numerous aspects of biblical studies from archaeology to art. I hope that, as someone who appreciates constructive mischief, he will enjoy what I am offering here. And for one who knows well (what) building a nation means, I think I have a fitting topic.

When Eben and I first met, the talk was often about 'minimalism', a term that for a while was attached to those scholars who opted to cease writing ancient Israelite history not only by starting with biblical stories and gradually dismantling them, but also by starting with other evidence and trying to explain the stories as stories. Such a task seemed negative to those for whom historical value was the only virtue of this material, but from the outset there was a positive agenda: to understand what these stories were trying to convey. There were different kinds of explanation: some, notably Thomas Thompson of Copenhagen (for a fairly full account of his approach, see Thompson 2013), have favoured explanations in the line of common mythic and literary tropes; others, like Liverani (2014), have interpreted them as functions of constructed memory, representing the past in terms of contemporary ideological or cultural factors, and thus yielding a different historical portrait.

One aspect of the 'minimalist' programme was to begin addressing texts at their latest possible date [terminus ad quem], rather than the earliest possible [terminus a quo]. Such dates questioned the assumption that the contents of 'historical writings' contained reliably known data. The amount of data presumed to be known determined either a 'minimalist' or a 'maximalist' stance. Obviously, certain kinds of religious and Zionist agendas (but let us be clear, not all) confused what was essentially a technical exegetical and archaeological enterprise.

Minimalist and maximalist starting points are both in principle defensible, as the evidence available is assessed with a minimum of bias, but the effect of each is different. On the (theoretical) assumption that there is only a single history which both positions are aiming to reconstruct from the texts, a terminus a quo approach can move only one way - towards later dating - while a terminus ad quem approach can only move earlier. Maximalism is productive where it discards the historical value of texts (which means 'erasing history' in Halpern's phrase from 1995), while minimalism moves forward by seeking to go earlier wherever possible (which could be described to Halpern as replacing an erased false history with a better one). The essential point is that as one method tends to 'lose history', the other gains it: the future of a minimalist agenda is positive, the maximalist[s] negative. What follows is an illustration of how the positive agenda of 'minimalism' works to create history, using the figure of the Israelite king Jeroboam II.

Note: The collection entitled 'Eben Scheffler Festschrift', sub-edited by Jurie H. le Roux (University of Pretoria) and Christo Lombaard (University of South Africa).

$\uparrow$, 1945-2018. 


\section{Jeroboam I and the founding of Israel}

Considerable attention has been paid in recent years to the kingdom of Jeroboam ben Joash, who ruled the kingdom of the 'house of Omri' at its greatest extent (cf. Römer 2017; Berlejung 2009; Finkelstein \& Römer 2017; Pakkala 2008). According to 2 Kings 14:25 'he restored the border of Israel from Lebo-hamath as far as the Sea of the Arabah', and (14:28) 'recovered Damascus and Hamath'. This territory (as pointed out by Römer 2017:373-374) is credited with a territorial restoration that recalls the borders of the 'United Monarchy' under David and Solomon. In the same volume, Knauf argues that we can apply to Jeroboam II achievements that biblical writers attributed to other agents, especially Jeroboam ben Nebat and also Solomon (Knauf 2017:301, 303).

This line of investigation leads in two directions: towards not just the activities that can be historically assigned to Jeroboam ben Joash but also towards the figure of Jeroboam ben Nebat, the biblical founder of the Kings' version of Israel, a kingdom created by the secession of 10 (or 11?) tribes from the rule of David. The portrait of a 'house of Israel' as a 'revolt' or 'rebellion' is contradicted in 1 Samuel, which suggests this 'Israel' to have been simply a continuation of an earlier polity, but this has to be ignored by the writers of Kings, for whom it is important that Jeroboam ben Nebat is dubbed the creator of an idolatrous Israel, promoting the worship of bull images at the cult centres of Dan and Bethel. He is created as the archetype of all successive kings of Israel and the ultimate instigator of its eventual disappearance.

What Jeroboam ben Nebat actually achieved, and indeed whether he existed, is difficult to determine. His story is bound up with the ' $[U]$ nited $[M]$ onarchy' of Solomon' which, as far as the evidence permits, can be dismissed as fictional. Quite apart from the lack of any solid archaeological evidence, I have argued (Davies 2013) that the existence of this 'United Monarchy' can be resolved by means of literary rather than archaeological means. As a consequence, we must ask whether Jeroboam's 'rebellion' ever occurred, and, indeed, whether he existed at all and is not part of the larger literary fiction featuring David and Solomon. Few historians have actually gone as far as to deny that he existed, and Finkelstein has made a detailed case for his historicity (Finkelstein 2017:63-82, esp. 80-82); Frevel, on the contrary, interprets the archaeological evidence differently (see the discussion in Frevel 2016:151-157, 192-193), and seems to doubt that this Jeroboam existed.

One way to explain Jeroboam ben Nebat as a fiction would be to cast him as a Doppelgänger of Jeroboam ben Joash. Römer argues (2017:376) - though without going as far as to deny Jeroboam ben Nebat's existence - that 'the story of 1 Kings 12 should be considered as a transfer of events that happened during the time of Jeroboam II to the beginnings of the Northern kingdom'. Grabbe (2007), who also specifically considers whether Jeroboam ben Nebat was modelled on Jeroboam ben Joash, disagrees, concluding that whether or not the account of Jeroboam I is fictional, it is not modelled on the reign of Jeroboam II (Grabbe 2007:116) and agrees with Finkelstein that archaeological evidence from Tirzah and Shechem, along with the account of Jeroboam's residence in Egypt, suggest that he did indeed exist. He adds that Jeroboam ben Nebat is mentioned, along with Rehoboam, in the 'chronicles of the kings of Judah', cited in 1 Kings 14-15 (Grabbe 2007:118). While the apparent absence of David's or Solomon's kingdom from these 'chronicles' might argue against the historicity of their reigns, we are not necessarily dealing with reliable historical records in any case: the very existence of a 'kingdom of Judah' before the late 8th century, let alone one maintaining a record of successive kings from the 9th century, casts some doubt on such a 'chronicle' (on the artificiality of the royal sequences of Kings, see further Auld 2007:337-343).

\section{Jeroboam ben Joash and the founding of Israel}

Whether Jeroboam's profile as the founder of the 'Israel' of the books of Kings is dubious, together with the degree to which he may be considered an 'avatar' or 'rhetorical ghost' of Jeroboam ben Joash, transferred to an earlier time - indeed, to create an earlier time - all recent commentators accept that the installation of temples at Dan and Bethel cannot be attributed to him, or at least not one in Dan, which belonged to the Israelite kingdom only briefly in the early 8th century, and thus in the time of Jeroboam ben Joash. Historically, this Jeroboam belongs to the summit of the kingdom's existence rather than its beginnings, and yet I would like to suggest that he was, and not unintentionally, the founder of an 'Israel' that outlasted the historical kingdom.

The questions that lead to this suggestion are: what was intended by the building of temples in Dan and Bethel? And what were the actual consequences of these foundations? Both are, to some extent, taken up by Römer's essay (2017:372-382), neatly entitled 'How Jeroboam II became Jeroboam I', and the following remarks explore some of the implications of Römer's thesis.

The two temple sites have to be considered as supplements rather than alternatives to the royal cult in Samaria, to which there are both biblical and extra-biblical clues. Hosea 8:5-6, discussed by Römer, implies a calf statue in Samaria, while Amos 8:14 cites 'Ashimah of Samaria' (on the relevance of Amos, see Levin 1995:307-317). Outside the Bible, the Kuntillet Ajrud finds and the reference there to 'Yahweh of Samaria' points to a strong connection with the northern kingdom (see Mastin 2011:69-85), indicating that in the early 8th century, Jeroboam ben Joash's Israel, at a minimum, controlled the trade route between Gaza and Aqaba (many scholars would suggest a more extensive presence in this region).

If the cult in Samaria was a city and/or dynastic cult, the cults of Dan and Bethel were almost certainly devoted to either a different deity or the same deity under another name, 
or as a more localised version of this god (the distinction is elusive and complicated). Dan and Bethel stood at the northern and southern borders of the kingdom, as fortresses might well have done. However, these places did not defend territorial borders: as cultic sites they aligned the deity to the territory of the kingdom of Israel.

This deity was a god of Israel, which suggests the name 'el yisra'el. Na'aman (2017:76-95) has suggested the deity was 'Yahweh', but the dominance of 'el yisra' el in the Hebrew Bible, distributed throughout every part of that canon, points to an Israelite and a Judahite title that most probably has a cultic base. Two further pieces of evidence suggest that the aim of such a cult was the creation of a new, inclusive ethnic identity of 'Israel'. Whatever the existence of such an identity among the populations of the kingdom before Jeroboam's accession, the enlargement of the realm had introduced other populations to whom such an identity had not attached, and thus the aim of reconfiguring what was in reality a territorial kingdom into something like a tribal one is understandable at this time, rather than at any other. The most obvious evidence of such an aim is the development of the figure of Jacob, whose association with Bethel is probably older than the 8th century. But, as argued by Finkelstein and Römer (2014, 2017; Römer 2017), the naming of Jacob as 'Israel' in Genesis 32 points to the previous 'god of Jacob' becoming the 'god of Israel'. This identification, in due course, led to the elaboration of a tradition in which, after the admission of Judah, 12 'tribes of Israel' were identified with 12 sons of Jacob.

Perhaps a division into corresponding administrative districts in Jeroboam's kingdom (see Kleiman 2017) can be inferred; Knauf (2017) has suggested the transfer of some achievements of Jeroboam to Solomon, but he did not include the creation of such districts.

A second argument for Jeroboam's intentions is also argued by Römer: the adoption of an 'exodus' narrative as part of this new cult: 'officially established under Jeroboam', as he puts it (Römer 2017:377). Such a move further suggests an attempt to create a kind of national identity by means of a common foundation myth. This hypothesis must, obviously, confront the problem of explaining the origins of such a story, for which no one compelling solution has yet been offered. The likelihood is that this story already existed among part of the population. Under Jeroboam, however, as Finkelstein has suggested, it assumes a written form (Finkelstein 2017:163), and thus becomes canonised as the 'national memory' that it will certainly become. Importantly, it is not a myth of the foundation of a kingdom of Israel, but of a people of Israel.

In dealing with the problem of 'biblical Israels', one oftenoverlooked feature is how the political definition represented in the inscriptional evidence and in the books of Kings is to be related to an ethnic definition that characterises the Pentateuch (and much of Joshua-Judges). The older - and biblical - view that the political emerged as a political expression of the ethnic is, in recent research, being reversed, and the reversal explains how the people of Judah came to understand themselves as part of Israel. There is little evidence anywhere in the Bible of Judah belonging to a political Israel, or wishing to do so. The account of Solomon's reign over a single kingdom constitutes a singular exception to the portrait elsewhere of two separate kingdoms (and 'houses'). At whatever time Judahites came to regard themselves as 'Israelites', they clearly adopted an identity that was not political, and almost certainly no longer political.

The Assyrian province of Samaria suffered considerable population transfer, a policy adopted by the Assyrians partly to dismantle political identities. But the inhabitants of the province of Samaria continued the worship of the god of the land of Israel, as even the books of Kings, which claim that Israel had gone completely into exile, acknowledge (2 Kings 17). The explanation given is that they were taught the mishpat of this god (named as Yahweh) by a priest sent from Bethel. Apart from this, the book of Jeremiah, at least more than a century after the end of the kingdom, addresses the 'house of Israel', sometimes alongside the 'house of Judah'. The existence of a Samaritan Pentateuch is further evidence not only that an Israelite ethnic identity was sustained in Samaria, but also that Judah was incorporated into that identity. In my view, this incorporation took place during the long period (150 years) of Benjaminite government in Judah, under which Bethel functioned, as it always had, as the house of the 'god of Israel'. The location of Benjamin, and of Bethel itself, within the kingdom of Israel before 722 BCE also suggests the kind of fraternal relationship between the neighbouring provinces that, together with a sharing of the cult at Bethel, facilitated the incorporation of Judahites into the family of Jacob and/or Israel.

Jeroboam ben Nebat may or may not have been the founder of a kingdom that persisted for about two centuries. But Jeroboam ben Joash is the probable founder of another Israel that has historically been more important. Biblical scholarship has, until very recently, concentrated its attention on scriptures emanating mostly from Judah that contain a good deal of polemic against the kingdom of Israel, functioning also as a cypher for the province of Samaria. In recent years, however, Israel and Samaria have begun to receive more attention as the original home of all Israelite identities, and from which most of the Pentateuchal story originated. Perhaps Omri and Jeroboam ben Joash deserve the place in histories of ancient Israel and Judah formerly inhabited by the Judahite heroes David, Solomon, Hezekiah and Josiah. If so, that process represents a major example of the minimalist task: not 'erasing history', but recreating it.

\section{Acknowledgements Competing interests}

The author has declared that no competing interests exist. 


\section{Author contributions}

P.D. is the sole author of this article.

\section{Ethical consideration}

This article followed all ethical standards for research without direct contact with human or animal subjects.

\section{Funding}

This research received no specific grant from any funding agency in the public, commercial or not-for-profit sectors.

\section{Data availability statement}

Data sharing is not applicable to this article as no new data were created or analysed in this study.

\section{Disclaimer}

The views and opinions expressed in this article are those of the author and do not necessarily reflect the official policy or position of any affiliated agency of the author.

\section{References}

Auld, G., 2007, 'Reading Kings on the divided monarchy: What sort of narrative?', in H.G.M. Williamson (ed.), Understanding the history of ancient Israel, pp. 337-343, Oxford University Press, Oxford.
Berlejung, A., 2009, 'Twisting traditions: Programmatic absence-theology for the Northern Kingdom in 1 Kgs 12:26-33* (the 'Sin of Jeroboam')', Journal of Northwest Semitic Languages 35, 1-42.

Davies, P.R., 2013, The forgotten Kingdom: The archaeology and history of Northern Israel, SBL Finkelstein, Atlanta.

Finkelstein, I., 2017, 'A corpus of North Israelite texts in the days of Jeroboam II', Hebrew Bible and Ancient Israel 6(3), 372-382. https://doi.org/10.1628/2192227 17X15162808430810

Finkelstein, I. \& Römer, T., 2014, 'Comments on the historical background of the Jacob narrative in 'Genesis', Zeitschrift für die alttestamentliche Wissenschaft 126:317-38. https://doi.org/10.1515/zaw-2014-0020

Finkelstein, I. \& Römer, T., 2017, 'Jeroboam I? Jeroboam II? Or Jeroboam 0?- Jeroboam in History and Tradition', in O. Lipschits, Y. Gadot \& M.J. Adams (eds.), Rethinking Israel: Studies in the History and Archaeology of Ancient Israel in Honor of Israel Finkelstein, pp. 115-124, Eisenbrauns, Winona Lake.

Frevel, C., 2016, Geschichte Israels, Kohlhammer, Stuttgart.

Grabbe, L.L., 2007, Ancient Israel: What do we know and how do we know it?, T\&T Clark, London.

Halpern, B., 1995, 'Erasing history: The Minimalist Assault on Ancient Israel', Bible Review 11, 26-35, 47.

Kleiman, A., 2017, 'A North Israelite Royal administrative system and its impact on late-monarchic Judah', Hebrew Bible and Ancient Israel 6, 354-371. https://doi. org/10.1628/219222717X15162808430793

Knauf, E.A., 2017, 'Jeroboam ben Nimshi: The Biblical Evidence', Hebrew Bible and Ancient Israel 6, 290-307. https://doi.org/10.1628/219222717X15162808430766

Levin, C., 1995, 'Amos und Jeroboam I.', Vetus Testament 45, 307-317. https://doi. org/10.1163/1568533952663206

Liverani, M., 2014, Israel's History and the History of Israel, Routledge, London.

Mastin, B., 2011, 'Who built and used the Buildings at Kuntillet Ajrud?', in J. Aitken, K. Dell and B. Mastin (eds.), On stone and scroll: Essays in honour of Graham Ivor Davies, pp. 69-85, De Gruyter, Berlin.

Na'aman, N., 2017, 'In search of the Temples of YHWH of Samaria and YHWH of Teman', Journal of Ancient Near Eastern Religions 1, 76-95. https://doi.org/ 10.1163/15692124-12341287

Pakkala, J., 2008, 'Jeroboam Without Bulls', Zeitschrift für die alttestamentliche Wissenschaft 120(4), 501-525. https://doi.org/10.1515/ZAW.2008.031

Römer, T., 2017, 'How Jeroboam II became Jeroboam I', Hebrew Bible and Ancient Israel 6, 372-382. https://doi.org/10.1628/219222717X15162808430810

Thompson, T.L., 2013, Biblical narrative and Palestine's history, CRC Press, London. 